DOI: 10.46340/eppd.2020.7.5.27

Pavlo Barbul

ORCID ID: https://orcid.org/0000-0003-1444-7383

V.M. Koretsky Institute of State and Law of the National Academy of Sciences of Ukraine, Kyiv

\title{
ON SPECIFIC ISSUES OF LEGAL SUPPLY OF ORGANIZATIONAL-FUNCTIONAL STRUCTURE OF THE MINISTRY OF DEFENSE OF UKRAINE
}

\author{
Павло Барбул \\ Інститут держави і права ім. В.М. Корецького НАН України, м.Київ

\section{ЩОДО ОКРЕМИХ ПИТАННЬ ПРАВОВОГО ЗАБЕЗПЕЧЕННЯ ОРГАНІЗАЦІЙНО-ФУНКЦІОНАЛЬНОЇ СТРУКТУРИ МIНICТЕРСТВА ОБОРОНИ УКРАЇНИ}

The article discusses the constituent elements of the organizational and functional structure of the Ministry of Defense of Ukraine (Ministry of Defense) in their unity and connection. Organizational-functional structure of the Ministry of Defense is a set of positions and structural subdivisions of the Ministry, which exist in internally organized relations in order to achieve the distributed tasks and implementation of certain functions of the Ministry by implementing the powers assigned to them. Emphasis is placed on the interdependence of tasks, functions, powers, and organizational structure of the Ministry. It is noted that the functional structure is primary in relation to the organizational. In addition, the choice of organizational and functional structure of the Ministry of Defense is influenced by a number of factors. They are also important to take into account when improving the legal support of the organizational and functional structure of the Ministry of Defense.

Keywords: Ministry of Defense of Ukraine, organizational-functional structure, tasks, functions, powers, competence, structural subdivisions and position.

Постановка проблеми. Ефективність державного управління сферою оборони в Україні безпосередньо пов'язується з тим, як організоване та функціонує Міністерство оборони України (далі- Міноборони). Важливо, щоб визначеним для нього завданням та покладеним на нього функціям відповідала його організаційна структура. Невідповідність між поставленими перед Міноборони завданнями та функціями і його організаційною структурою може негативно позначитися на здатності цього міністерства вчасно і повною мірою відповідати на виклики і загрози, що постають перед державою. Отже, існує практична потреба дослідження теоретико-прикладних аспектів правового забезпечення організаційно-функціональної структури Міноборони.

Аналіз останніх досліджень та публікацій. Досліджуючи особливості організаційнофункціональної структури Міноборони, важливо враховувати наявний науковий доробок українських вчених-адміністративістів, які досліджували питання адміністративно-правового регулювання сфери оборони, організації та функціонування системи органів виконавчої влади, зокрема, В.Б. Авер янова, О.Ф. Андрійко, Ю.В. Георгієвського, В.А. Дерець, Л.С. Кисіль, В.П. Нагребельного, С.В. Осауленко, В.В. Сокуренка та ін., а також представників науки державного управління та військової науки.

Виділення невирішених раніше частин загальної проблеми. У вітчизняній адміністративноправовій літературі проблематиці організаційно-функціональної структури Міноборони приділяється недостатня увага. Хоча саме адміністративно-правова наука має відігравати важливу роль у процесі реформування Міноборони, створюючи теоретичне підгрунтя тих змін, яких потребує Міноборони як центральний орган виконавчої влади (далі - ЦОВВ), що здійснює державне управління у відповідній сфері. Мають місце суперечності та неточності у визначенні завдань, функцій, повноважень, організаційної структури Міноборони. Не завжди акцентується увага на взаємозалежності 
та взаємообумовленості організаційної та функціональної складових Міноборони. Взаємовплив цих складових важливо враховувати, удосконалюючи правове забезпечення його організаційнофункціональної структури.

Метою дослідження $\epsilon$ охарактеризувати складові елементи організаційно-функціональної структури Міноборони в їх єдності та зв'язку, а також визначити, які особливості варто враховувати, удосконалюючи правове забезпечення цього міністерства.

Виклад основного матеріалу. До категорії «організаційно-функціональна структура» звертаються дослідники адміністративного права, аналізуючи правовий статус органів виконавчої влади, адміністративно-правове регулювання їх діяльності, вивчаючи їх внутрішню будову. Загальнотеоретичні визначення організаційно-функціональної структури відображають ії зміст. Складовими організаційно-функціональної структури $\epsilon$ системоутворюючі елементи, які перебувають в управлінських відносинах та взаємодіють між собою (організаційний аспект), та функції, якими наділені системоутворюючі елементи і які вони реалізують у відповідних управлінських відносинах та взаємодіючи між собою (функціональний аспект).

В адміністративно-правовій доктрині домінує позиція, що організаційно-структурні елементи системи управління мають бути функціонально узгоджені, а їх кількість об'єктивно обумовлена. Наслідком цього стане таке упорядкування структури різних ланок, що не призводитиме до посилення громіздкості системи управління в цілому, зниження їі керованості. Крім того, з метою найбільш повної реалізації можливостей організаційних структур, необхідно намагатися максимально забезпечити їх стабільність ${ }^{1}$.

У разі виникнення необхідності в реалізації нової функції органу виконавчої влади потрібно визначити, чи міг би її виконувати вже наявний структурний підрозділ (чи посадовець) органу влади; чи структура органу виконавчої влади потребує реорганізації без створення нового структурного підрозділу (посади); чи є потреба у створенні нового структурного підрозділу (посади). У випадку зникнення необхідності у виконанні відповідної функції структура органу виконавчої влади може бути реорганізована; створений для виконання цієї функції структурний підрозділ (посада) ліквідується.

При цьому термін «організаційна структура» може аналізуватися і самостійно, без конкретної «прив'язки» до функцій. Це залежить від завдань, які вирішує дослідник. На підтвердження даного положення можна навести точку зору В.Б. Авер'янова, який заперечував проти абсолютизації уявлення, ніби структурний і функціональний підходи до управління можуть бути ефективними лише у випадку, коли застосовуються у єдності. Не виключається і не зменшується доцільність і правомірність використання у конкретних пізнавальних ситуаціях якогось одного або деяких з усієї сукупності його аспектів. Хоча виникають і пізнавальні завдання, котрі вимагають органічного поєднання структурного та функціонального підходів. Зокрема, дослідження співвідношення змісту діяльності та організаційних структур управлінського апарату виходить за власні пізнавальні можливості як структурного, так і функціонального аспектів системного підходу. Структурнофункціональна характеристика апарату управління розкриває найбільш суттєві ознаки побудови та діяльності апарату ${ }^{2}$.

Для вирішення завдань удосконалення адміністративно-правового регулювання діяльності Міноборони структурно-функціональний підхід доцільно застосовувати в органічній єдності. Варто зазначити, що вибір елементів організаційної структури органу виконавчої влади визначають функції цього органу. Тобто, ефективність діяльності Міноборони залежатиме від того, наскільки його організаційна побудова (структура) відповідатиме функціям, які покладені на це міністерство, та сприятиме їх реалізації. При цьому первинними $є$ функції, а вторинною - організаційна структура.

Організаційну структуру Міноборони утворюють (складають) відповідні структурні підрозділи та посади, які перебувають у певних взаємовідносинах. В науковій літературі зазначається, що при аналізі структури органу виконавчої влади мова повинна йти: 1) про склад його структурних підрозділів; 2) про встановлені схеми зв'язків організаційного підпорядкування підрозділів; 3) про нормативно закріплений порядок розподілення між структурними підрозділами задач,

\footnotetext{
${ }^{1}$ Боделан, В. (2013). Організаційно-функціональні структури: особливості впливу чинників їх побудови на ефективність функціонування організаційного механізму державного управління. Публічне управління: теорія та практика, 3, 53-59.

${ }^{2}$ Авер'янов, В.Б. (1999). Діяльність апарату державного управління: складові змісту. Державне управління в Украӥні. Київ, 69-73.
} 
повноважень, відповідальності; 4) про схему інформаційних потоків та зв'язків. Кожний з цих елементів виступає відносно самостійною організаційно-правовою характеристикою структури органу виконавчої влади, що відображається в правовому регулюванні його організації. Структура органу - це його внутрішня будова, яка втілюється в єдності структурних підрозділів, їх взаємозв'язків та підпорядкованості, нормативно закріпленого порядку (схеми) розподілення між ними покладених на орган завдань та повноважень, юридичної відповідальності і встановленої схеми інформаційних потоків, зв'язків ${ }^{1}$.

Поділяємо підхід, відповідно до якого функції - це відносно самостійні та якісно однорідні складові діяльності органів, які характеризуються цільовою спрямованістю. Цільова спрямованість функцій управління - найважливіший аргумент на користь визначення самостійності тієї чи іншої функції. Причому, в даному випадку йдеться не взагалі про будь-які цілі (завдання). Для виокремлення конкретних функцій відповідних органів вирішальне значення має лише певний вид (група) цілей (завдань), що стоять перед цими органами ${ }^{2}$.

Функціональний аспект організаційно-функціональної структури не зводиться до означення його лише через функції. Функції аналізуються в поєднанні з повноваженнями та компетенцією. Отже, функціональний аспект організаційно-функціональної структури будь-якого органу державної влади характеризується тріадою «функції - повноваження - компетенція», яка визначається цілями та завданнями діяльності органу виконавчої влади. Функція не виконуватиметься, а результат діяльності органом виконавчої влади не досягатиметься, якщо відсутні необхідні повноваження або ж їх недостатньо. Досягнення результату буде можливим за умови, що функції адекватно відповідають цілям та завданням діяльності органу.

В основі дієвості тріади «функції - повноваження - компетенція» лежить точне і правильне визначення цілей і завдань органу виконавчої влади. Завдання визначаються в компетенційних актах про органи виконавчої влади. Для їх виконання визначаються відповідні функції. Для реалізації функцій орган виконавчої влади наділяється певними чітко визначеними повноваженнями. Такий алгоритм функціонування забезпечує ефективну діяльність органу виконавчої влади та результативність його роботи. Отже, у першу чергу слід визначитися із завданнями органу виконавчої влади.

Щодо повноважень органів виконавчої влади, то уданому випадку усталеним $є$ підхід, відповідно до якого повноваження - це сукупність прав і обов'язків, які закріплені законодавством за органом. Як правило, йдеться про «право-обов`язок» органу виконавчої влади, адже для нього реалізація права теж $є$ його обов'язком.

Компетенція державного органу - це сукупність установлених законом владних повноважень для здійснення функцій і завдань, покладених на нього державою, а повноваження - сукупність прав та обов 'язків органу ${ }^{3}$. Будь-який орган представляє державу, але не як окрему особу у праві й тільки в межах своєї компетенції. Саме компетенція є стрижневою і якісною характеристикою державного органу, який не має жодних суб'єктивних прав ${ }^{4}$.

Вищенаведене не означає, що можна не розрізняти права та обов'язки в компетенції органу. Права та обов'язки зберігають у рамках компетенції органу державного управління відносно самостійний характер. Право у встановлених межах дає можливість альтернативного вибору при вирішенні того чи іншого питання. У ряді випадків реалізація того чи іншого права органу державного управління цілком залежить від його вибору: приймати чи ні рішення з того чи іншого питання. Обов`язок не надає такої свободи вибору при вирішенні конкретного питання, жорстко регламентуючи дії органу ${ }^{5}$.

\footnotetext{
${ }^{1}$ Полюхович, В.І. (1999). Структура і діяльність державної податкової служби України: організаційноправовий аспект: автореферат дисертації кандидата юридичних наук. Київ: Інститут держави і права ім. В.М. Корецького НАН України, 20.

2 Авер'янов, В.Б. (ред.) (2007). Адміністративне право України. Академічний курс: підручник у двох томах: Том 1. Загальна частина. Київ: ТОВ «Видавництво «Юридична думка», 592.

${ }^{3}$ Осауленко, С.В. (2010). Адміністративно-правовий статус Кабінету Міністрів Украӥни: автореф. дис. ... канд. юрид. наук. Одеса.: Одеська національна юридична академія, 20.

${ }^{4}$ Шаповал, В.М. (2003). Феномен державного органу (органу держави) або органу державної влади: теоретико-правовий і конституційний аспекти. Право Украӥни, 8, 25-30.

${ }^{5}$ Ківалов, С.В., Лавренова, О.І. (2015). Адміністративно-правовий статус державної служби як иентрального органу виконавчої влади. Одеса: Фенікс, 190.
} 
У зв’язку з цим не можна не погодитися з точкою зору Ю.В. Георгієвського, який підкреслив, що нормотворець, визначаючи компетенцію суб`єктів централізованого та територіального управління, в одних випадках не розділяє, вказуючи на повноваження, а інших все ж таки розділяє їх права та обов’язки. Для визначення статусу і компетенції владних суб ‘ктів часто поряд 3 терміном «право» (в суб’єктивному значенні) використовується термін «владні повноваження» ${ }^{1}$.

Окремі дослідники наголошують на тому, що в нормативно-правових актах потрібно чітко прописувати і виділяти адміністративні права суб'єкта права, не змішуючи їх з адміністративними обов'язками чи іншими категоріями юриспруденції, такими як «компетенція» та «повноваження». У нормативно-правових актах, якими затверджено положення про суб`єкти публічної адміністрації, часто не виокремлюються адміністративні обов'язки і права: вони узагальнюються й об'єднуються загалом компетенцією. Такий підхід методологічно видається хибним, а практично - навіть шкідливим, адже «змішування» обов'язків і прав владного суб'єкта адміністративного права часто призводить до негативних наслідків, коли посадова особа суб'єкта публічної адміністрації внаслідок нечіткості формулювання владної компетенції може вийти за межі повноважень, наданих їй нормами адміністративного права, і таким чином порушити права і свободи осіб ${ }^{2}$

Під повноваженнями публічних органів управління усфері оборони В.В. Сокуренко обгрунтовано пропонує розуміти систему прав та обов'язків (власних або делегованих), наданих державою органам публічної адміністрації, що здійснюють адміністрування у сфері оборони, їх посадовим та службовим особам з метою забезпечення прав, свобод та законних інтересів громадян України, іноземців та осіб без громадянства ${ }^{3}$.

За результатами дослідження поняття «компетенція» Л.С. Кисіль вірно зазначає, що підходи до визначення компетенції $\epsilon$ різноманітними. Натомість автори єдині увизнанні тісного i нерозривного зв'язку функцій, повноважень і компетенції органів управління ${ }^{4}$.

Дискусія про співвідношення функцій та компетенції органу управління триває ще 3 радянського періоду. Узагальнюючи ключові положення цієї тривалої дискусії, В.Б. Авер'янов зазначав, що основними були дві позиції. На думку І.Л. Бачило, функції входять як складові елементи до компетенції та визначають «що» робить орган ${ }^{5}$. Б.М. Лазарєв стверджував, що елементами компетенції органу управління виступають не самі функції як такі, а покладені на нього, по-перше, загальне право (щодо керованого об'єкта) та обов'язок (перед державою) виконувати певні функції, по-друге, комплекс прав і обов'язків (повноважень), що необхідні для реалізації цих функційб.

Подальший аналіз цього питання В.Б. Авер`яновим підтвердив висновок про те, що функції не $\epsilon$ однопорядковими з повноваженнями, як елементами компетенції органу, а виражаються уній шляхом правового закріплення (регламентації) останніх ${ }^{7}$. Він підкреслив органічний зв'язок у змісті управлінської діяльності функцій та державно-владних повноважень (прав і обов'язків), що входять до компетенції органів управління. Стосовно компетенції, то В.Б. Авер'янов визначає ії як юридичне вираження управлінських функцій шляхом закріплення за органом у спеціальних правових актах (так званих компетенційних, або статусних) цілей, завдань і необхідних для їх виконання повноважень ${ }^{8}$.

Варто погодитися з думкою про те, що питання термінологічної виваженості при застосуванні законодавцем термінів «завдання», «функції», «повноваження», «компетенція» $є$ наразі невирішеним і потребує подальшого теоретичного і практичного вирішення'.

\footnotetext{
${ }^{1}$ Георгієвський, Ю.В. (2015). Компетенція органів публічної влади: теорія і практика застосування. Київ: Логос, 345.

${ }^{2}$ Горбач, М.I. (2017). Адміністративно-правовий статус суб єктів адміністративного права: теорія і практика. Київ: Науково-дослідний інститут публічного права, 19.

${ }^{3}$ Сокуренко, В.В. (2015). Сфера оборони Украӥни: адміністративно-правове регулювання: монографія. Київ, Національна академія внутрішніх справ, 544 .

${ }^{4}$ Кисіль, Л.Є. (1998). Керівник підприємства: компетениія та адміністративна відповідальність. Київ: Інститут держави і права ім. В.М. Корецького НАН України, 80.

${ }_{5}^{5}$ Бачило, И.Л. (1976). Функции органов управления: правовые проблемы оформления и реализации. Москва, 198.

6 Лазарев, Б.М. (1972). Компетенция органов управления. Москва, 280.

${ }^{7}$ Аверьянов, В.Б. (1979). Функиии и организаиионная структура органа государственного управления. Киев, 150.

${ }^{8}$ Авер'янов, В.Б. (1999). Діяльність апарату державного управління: складові змісту. Державне управління в Україні. Київ, 69-73.

${ }_{9}^{9}$ Андрійко, О.Ф., Нагребельний, В.П., Дерець, В.А., Кисіль, Л.С., Педько, Ю.С., Тимощук, В.П. (2014).

Теоретико-прикладні аспекти розвитку адміністративного права та державного управління в Україні. Правова держава, 182-203.
} 
Складовими елементами організаційно-функціональної структури Міноборони є завдання, функції, повноваження, компетенція міністерства (функціональна структура) та посади і структурні підрозділи (організаційна структура). Функціональна структура визначає організаційну. Суб єктами правового забезпечення організаційно-функціональної структури Міноборони $є$ Верховна Рада України, Кабінет Міністрів України (КМУ) і саме міністерство. Організаційно-функціональною структурою Міноборони є сукупність посад та структурних підрозділів міністерства, які перебувають між собою у внутрішньоорганізаційних відносинах та взаємозв'язках 3 метою досягнення розподілених між ними завдань та виконання визначених функцій міністерства шляхом реалізації закріплених за ними повноважень.

За період незалежності України організаційно-функціональна структура Міноборони зазнавала частих змін. Змінювалося адміністративно-правове регулювання завдань цього міністерства, уточнювалися функції та повноваження, змінювалися структурні підрозділи. Зміни у завданнях міністерства, що відбувалися за період з 1991 року до теперішнього часу, не могли не позначитися на їх сучасному стані.

В ході проведення оборонної реформи в Україні в організаційній структурі Міноборони в останні роки відбувалися певні зміни, що мають сприяти посиленню спроможності міністерства формувати державну політику. Вони були наслідком зміни повноважень Міноборони, зокрема, прийняття нової редакції положення про міністерство.

Крім цього, в Україні з 2016 року в межах реформи державного управління відбувалося реформування 8 пілотних міністерств. Міноборони не входило до цього переліку. Однак, вважаємо, що в процесі удосконалення правового забезпечення організаційно-функціональної структури Мінооборони можуть бути використані підходи, запропоновані в межах реформи «пілотних» міністерств, а також врахований вже набутий досвід реформування.

На нашу думку, на вибір організаційно-функціональної структури Міноборони впливає низка загальних для всіх органів виконавчої влади факторів (чинників):

1) рівень, на якому перебуває орган у системі органів виконавчої влади. Міноборони є ЦОВВ, який забезпечує формування та реалізує державну політику з питань національної безпеки у воєнній сфері, сферах оборони і військового будівництва у мирний час та особливий період. В Україні вищим органом в системі органів виконавчої влади є КМУ. На місцевому рівні діють місцеві державні адміністрації та територіальні органи ЦОВВ;

2) місце, яке посідає міністерство у системі суб`єктів (Президент України, КМУ, Міноборони, Генеральний Штаб Збройних Сил України), які також здійснюють управління цією сферою на центральному рівні. Важливо враховувати особливості цієї системи, щоб уникати дублювання повноважень та компетенційних спорів;

3) орган виконавчої влади є політичним чи адміністративним. Міноборони, як вже зазначено вище, забезпечує формування та реалізує державну політику. Сучасне Міноборони повинно концентруватися на формуванні державної політики у сфері його відповідальності, а також повинно бути позбавлене невластивих для міністерства повноважень;

4) сфера, якою здійснює управління орган виконавчої влади. Так, Міноборони забезпечує формування та реалізує державну політику з питань національної безпеки у воєнній сфері, сферах оборони і військового будівництва.

Крім названих чинників, на вибір організаційно-функціональної структури Міноборони впливають також такі чинники: 5) визначення ключових для відповідної сфери питань, що потребують державного управління; бачення ідеального стану сфери державного управління та результатів, які необхідно досягти; 6) міжнародна ситуація; 7) фінансово-економічні можливості держави; 8) професійність посадових та службових осіб, які займаються нормопроектною діяльністю, готують компетенційний акт про орган виконавчої влади, тобто відповідають за розробку правових актів, якими здійснюється правове забезпечення його організаційно-функціональної структури.

Кожна сфера управлінської діяльності має свою специфіку. Тому на визначення організаційнофункціональної структури Міноборони впливають і спеціальні чинники (фактори). Зокрема, змістовне наповнення завдань, функцій та повноважень Міноборони залежить від того, здійснюється воно для мирного часу, для особливого періоду чи для умов війни.

Перелік чинників (факторів), які впливають на завдання, функції та структуру Міноборони, не обмежується вказаними факторами. У структурі та функціях Міноборони відображаються ті процеси військового будівництва, що відбуваються в Україні у певний час. На тенденції зміни 
структури і функцій Міноборони як ЦОВВ та органу військового управління значною мірою впливає багато інших взаємопов'язаних чинників. Серед них, з обгрунтованої точки зору Г.П. Ситника, найголовнішими є: загальна структура, склад та дислокація Збройних Сил України; чинне законодавство та військово-політичні рішення у сфері оборони і військового будівництва; військовополітичні зміни в геополітичному просторі; невирішеність тих чи інших проблемних питань реформування так званих «силових» міністерств у процесі адміністративної реформи в контексті розподілу повноважень і відповідальності органів державної влади, органів військового управління, місцевих державних адміністрацій та органів місцевого самоврядування за вирішення питань в оборонній сфері; вплив ринкових перетворень на структуру, механізми та шляхи матеріального, технічного та тилового забезпечення Збройних Сил України та ін. ${ }^{1}$.

Висновки. Удосконалюючи правове забезпечення організаційно-функціональної структури Міноборони, важливо враховувати взаємозалежність та взаємообумовленість завдань, функцій, повноважень та організаційної будови міністерства. Структурно-функціональний підхід доцільно застосовувати в органічній єдності. Варто також враховувати наступні чинники (фактори), які впливають на вибір організаційно-функціональної структури Міноборони: сфера, якою здійснюється державне управління; місце Міноборони в системі суб єктів, які здійснюють управління сферою оборони; рівень органів виконавчої влади, на якому перебуває Міноборони (центральний); міжнародну ситуацію; фінансово-економічні можливості держави; мирний час/особливий період/ умови війни та ін. Подальші наукові дослідження зазначеної проблематики можна спрямувати на аналіз основних напрямів розвитку правового забезпечення організаційної-функціональної структури Міноборони з урахування наведених особливостей та можливості використання в сучасних умовах в Україні зарубіжного досвіду.

\section{References:}

1. Averianov, V.B. (1999). Diialnist aparatu derzhavnoho upravlinnia: skladovi zmistu [Activities of public administration: components of content]. Derzhavne upravlinnia v Ukraini [Public administration in Ukraine]. Kyiv, 69-73. [in Ukrainian].

2. Averianov, V.B. (ed.) (2007). Administratyvne pravo Ukrainy. Akademichnyi kurs: pidruchnyk u dvokh tomakh: Tom 1. Zahalna chastyna [Administrative law of Ukraine. Academic course: textbook in two volumes: Volume 1. General part]. Kyiv: TOV «Vydavnytstvo «Iurydychna dumka». [in Ukrainian].

3. Averianov, V.B. (1979). Funktsyy y orhanyzatsyonnaia struktura orhana hosudarstvennoho upravlenyia [Functions and organizational structure of the government body]. Kyiv. [in Russian]. [in Russian].

4. Andriiko, O.F., Nahrebelnyi, V.P., Derets, V.A., Kysil, L.Ie., Pedko, Yu.S., Tymoshchuk, V.P. (2014). Teoretykoprykladni aspekty rozvytku administratyvnoho prava ta derzhavnoho upravlinnia v Ukraini [Theoretical and applied aspects of the development of administrative law and public administration in Ukraine]. Pravova derzhava [Law state], 182-203. [in Ukrainian].

5. Bachylo, Y.L. (1976). Funktsyy orhanov upravlenyia: pravovye problemy oformlenyia y realyzatsyy [Functions of the governing bodies: right problems of design and implementation]. Moscow. [in Russian].

6. Bodelan, V. (2013). Orhanizatsiino-funktsionalni struktury: osoblyvosti vplyvu chynnykiv yikh pobudovy na efektyvnist funktsionuvannia orhanizatsiinoho mekhanizmu derzhavnoho upravlinnia [Organizational and functional structures: features of the influence of factors of their construction on the efficiency of the organizational mechanism of public administration]. Publichne upravlinnia: teoriia ta praktyka [Public administration: theory and practice], no. 3, 53-59. [in Ukrainian].

7. Heorhiievskyi, Yu.V. (2015). Kompetentsiia orhaniv publichnoi vlady: teoriia i praktyka zastosuvannia [Competence of public authorities: theory and practice of application]. Kyiv: Lohos. [in Ukrainian].

8. Horbach, M.I. (2017). Administratyvno-pravovyi status sub`iektiv administratyvnoho prava: teoriia i praktyka [Administrative and legal status of subjects of administrative law: theory and practice]. Kyiv: Naukovo-doslidnyi instytut publichnoho prava. [in Ukrainian].

9. Kysil, L.Ie. (1998). Kerivnyk pidpryiemstva: kompetentsiia ta administratyvna vidpovidalnist [Head of the enterprise: competence and administrative responsibility]. Kyiv: Instytut derzhavy i prava im. V.M. Koretskoho NAN Ukrainy. [in Ukrainian].

10. Kivalov, S.V., Lavrenova, O.I. (2015). Administratyvno-pravovyi status derzhavnoi sluzhby yak tsentralnoho orhanu vykonavchoi vlady [Administrative and legal status of the civil service as a central executive body]. Odesa: Feniks. [in Ukrainian].

11. Lazarev, B.M. (1972). Kompetentsyia orhanov upravlenyia [Competence of governing bodies]. Moscow. [in Russian].

\footnotetext{
${ }^{1}$ Ситник, Г.П. (2004). Державне управління національною безпекою Украӥни: монографія. Київ, 408.
} 
12. Osaulenko, S.V. (2010). Administratyvno-pravovyi status Kabinetu Ministriv Ukrainy: avtoreferat dysertatsii kandydata yurydychnykh nauk [Administrative and legal status of the Cabinet of Ministers of Ukraine: the abstract of the dissertation of the candidate of legal sciences]. Odesa.: Odeska natsionalna yurydychna akademiia. [in Ukrainian].

13. Poliukhovych, V.I. (1999). Struktura i diialnist derzhavnoi podatkovoi sluzhby Ukrainy: orhanizatsiino-pravovyi aspekt: avtoreferat dysertatsii kandydata yurydychnykh nauk [Structure and activity of the state tax service of Ukraine: organizational and legal aspect: the abstract of the dissertation of the candidate of legal sciences]. Kyiv: Instytut derzhavy i prava im. V.M. Koretskoho NAN Ukrainy. [in Ukrainian].

14. Sytnyk, H.P. (2004). Derzhavne upravlinnia natsionalnoiu bezpekoiu Ukrainy: monohrafiia [State management of national security of Ukraine: monograph]. Kyiv. [in Ukrainian].

15. Sokurenko, V.V. (2015). Sfera oborony Ukrainy: administratyvno-pravove rehuliuvannia: monohrafiia [The sphere of defense of Ukraine: administrative and legal regulation: a monograph]. Kyiv: Natsionalna akademiia vnutrishnikh sprav. [in Ukrainian].

16. Shapoval, V.M. (2003). Fenomen derzhavnoho orhanu (orhanu derzhavy) abo orhanu derzhavnoi vlady: teoretyko-pravovyi i konstytutsiinyi aspekty [The phenomenon of a state body (state body) or a body of state power: theoretical, legal and constitutional aspects]. Pravo Ukrainy [Law of Ukraine], no. 8, 25-30. [in Ukrainian]. 


\title{
Zveme vás $k$ účasti v časopise!
}

\section{EVROPSKÝ POLITICKÝ A PRÁVNÍ DISKURZ}

Časopis vychází šestkrát ročně.

Články pro zveřejnění v prvním (únor) dílu časopisu jsou přijímány do dne 28 . ledna a musí byt publikováné do dne 28. února.

Články pro zveřejnění $\mathbf{v}$ druhém (duben) dílu časopisu jsou přijímány do dne 28 . března a musí byt publikováné do dne 30. dubna.

Články pro zveřejnění $\mathbf{v}$ třetím (červen) dílu časopisu jsou přijímány do dne 28 . května a musí byt publikováné do dne 30. června.

Články pro zveřejnění ve čtvrtém (srpen) dílu časopisu jsou přijímány do dne 1. srpna a musí byt publikováné do dne 31. srpna.

Články pro zveřejnění v pátém (ř́ijen) dílu časopisu jsou přijímány do dne 28. září a musí byt publikováné do dne 31. října.

Články pro zveřejnění $\mathbf{v}$ šestém (prosinec) dílu časopisu jsou přijímány do dne 28. listopada a musí byt publikováné do dne 31. prosince.

Objem - 10 - 30 stranek.

\section{Požadávky k rukopisům:}

Jazyk članků - česky, ukrajinský, angličtina, francouzština, němčina.

U článků podávaných v libovolném jazyce, nezbytně v angličtině musí být uvedeno :

Anotace objemem 700-900 znaků, název članku a úplná informace o autorovi: jméno a př́ímení, titul, akademický titul, prácovní funkce, postavení, zaměstnání.

Poznámky pod čarou - na každé stránce.

Odkazy na zdroje na konci článku - volitelný.

Bibliografické popisy zdrojů a odkazy by měly být poskytováné na základě norem APA (American Psychological Association).

Ilustrace k článkům (grafické a výkresy) musí byt uvedený ve formátu

TIFF nebo JPEG (každá postava v samostatném souboru/dokumentu).

Všimněte si, prosíme, při zpracování ilustraci že v časopisu není použit barevný tisk.

Rukopisy které nesplňují tyto technické požadavky redakční kolégie neregistruje a nebude probírat $\mathrm{s}$ účelem tisku a zveřejnění.

\author{
Adresa pro korespondenci: \\ E-mail: admedit@eppd13.cz \\ eppd13@gmail.com \\ ediskurs@gmail.com \\ Web: http://eppd13.cz
}

Adresa:

BEROSTAV DRUŽSTVO, Vlastislavova 562/15, 140 00, Praha 4 - Nusle 


\section{PŘÍKLADY ÚPRAVY BIBLIOGRAFICKÉHO POPISU ZDROJŮ A LITERATURY DLE POŽADAVKŮ APA-STYLE}

\section{V̌̌eobecná pravidla:}

Bibliografický popis zdrojů a literatury v odkazech na každé strance a v transliterovaném seznamu literatury (references) musí být zpracován na základě norem APA-Style, v souladu s požadavky APA (American Psychological Association). Níže jsou uvedeny př́klady zpracování nejběžnějších bibliografických zdrojů. Více informace dostanete na strance http://www.apastyle.org.

Při úpravě bibliografických popisů zdrojů a literatury dejte si pozor na způsob psaní: rovně a kurzivou (Italic) a také na postupnost umístění prvkủ odkazu.

Paginální odkazy na zdroje a literaturu se uvádí v původním jazyce (v jazyce originálů), totiž nepřekládají se a netransliterují se. Citace jsou také uváděný v původním jazyce článku.

Seznam literatury (references) na konci článku se uvádí latinkou. Pokud se musí uvést odkaz na články v písmu cyrilici (včetně článků v ukrajinštině nebo v ruštině) otištěné dřivě v časopisech a sbírkách, doporučujeme tuto variantu struktury bibliografických odkazů v sekci References:

- Jméno a př́ijmení autora/-ů (transliterace);

- Transliterováný název članku a jeho překlad v angličtině, který má být umístěný v hranatých závorkách: [];

- Název zdroje (transliterace) a překlad jeho názvy v jazyce anglickém: [];

- Výchozí údaje s anglickým zápisem.

V seznamu literatury (references) místo vydání pro zdroje v jazyce anglickém a ukrajinském se uvádí $\mathrm{v}$ angličtině, a název nakladatelství se transliteruje.

Pro automatickou transliteraci názvů zdrojů v písmu cyrilici dá se použit další stránky:

- pro zdroje v ruštině: http://www.translit.ru,

- pro zdroje v ukrajinštině: $\quad$ http://www.slovnyk.ua/services/translit.php .

Odkaz na web-zdroje se má sestavit dalším způsobem: jméno autora web-stránky, název stránky, název web-stránky (píše se kurzivou (Italic)), adresu web-stránky oddělenou znaky $<>$ : $<$ URL $>$ a pokud je možné datum poslední návštěvy/ náhledu web-stránky v zaoblených závorkách: () . Název měsíce nahlédnutí do web-stránky se uvádí v jazyce článku.

Pro vaše pohodlí jsou následující př́klady uvádění zdrojů a literatury rozdělený podle typu zdroje, a každý se uvádí ve dvou variantech po sobě: první je př́íklad odkazu na každé stránce, druhý je př́íklad odkazu na stejný zdroj, jenže jak se má uvádět v seznamu literatury (references).

\section{Monografie:}

Denning, D.E. (1998). Information Warfare and Security. Boston: Addison-Wesley Pub. Co, 99-100. Denning, D.E. (1998). Information Warfare and Security. Boston: Addison-Wesley Pub. Co. [in English].

Somit, A., Peterson, S. (2005). The Failure of Democratic Nation Building: Ideology Meets Evolution. New York: Palgrave Macmillan, 5.

Somit, A., Peterson, S. (2005). The Failure of Democratic Nation Building: Ideology Meets Evolution. New York: Palgrave Macmillan. [in English].

Тарасов, В. (1997). Советская дипломатия в период Корейской войны (1950-1953). Москва: Научная книга, 134-150.

Tarasov, V. (1997). Sovetskaya diplomatiya v period Koreyskoy voynyi (1950-1953) [Soviet diplomacy during the Korean War (1950-1953)]. Moskva: Nauchnaya kniga. [in Russian].

Калюжнова, Н.Я. Лидина, К.Л. Якобсона, А.Я. (2003). Регион на перекрестке Востока и Запада: глобализация и конкурентоспособность. Москва: ТЕИС, 14-21.

Kaljuzhnova, N.Ja., Lidina, K.L., Jakobsona, A.Ja. (2003). Region na perekrestke Vostoka i Zapada: globalizacija i konkurentosposobnost [The region at the crossroads of the East and West: globalization and competitiveness]. Moscow: TEIS. [in Russian]. 


\section{Článek v časopise:}

Bakircioglu, O. (2007). The Application of the Margin of Appreciation Doctrine in Freedom of Expression and Public Morality Cases. German Law Journal, 8, 07, 713-714.

Bakircioglu, O. (2007). The Application of the Margin of Appreciation Doctrine in Freedom of Expression and Public Morality Cases. German Law Journal, 8, 07, 713-714. [in English].

Musilová, K. (2017). Možnosti aplikace konceptu postmateriálního štěpení na substátních úrovních. Central European Political Studies Review, 19(1), 55-75.

doi:http://dx.doi.org/10.5817/CEPSR.2017.1.55

Musilová, K. (2017). Mozhnosti aplikace konceptu postmaterialnigo shtepeni na substatnih urovnih. Central European Political Studies Review, 19(1), 55-75. doi:http://dx.doi.org/10.5817/CEPSR.2017.1.55 [in Czech].

Nye, J.S., Owens, W.A. (1996). America's Information Edge. Foreign Affairs, March/April, 49-67.

Nye, J.S., Owens, W.A. (1996). America's Information Edge. Foreign Affairs, March/April, 49-67. [in English].

Задорожній, О., Медведєва, М. (2006). Імплементація міжнародних стандартів захисту прав людини в сфері боротьби з інфекційними хворобами в національному праві України. Український часопис міжнародного права, 1, 64-76.

Zadorozhnii, O., Medvedieva, M. (2006). Implementatsiia mizhnarodnykh standartiv zakhystu prav liudyny $\mathrm{v}$ sferi borotby $\mathrm{z}$ infektsiinymy khvorobamy $\mathrm{v}$ natsionalnomu pravi Ukrainy [Implementation of international human rights standards to combat infection disease in domestic law Ukraine]. Ukrainskyi chasopys mizhnarodnoho prava [Ukrainian Journal of International Law], no. 1, 64-76. [in Ukrainian].

\section{Teze a myšklenky konference:}

Григор'єва, Х.А. (2016). Правові аспекти приватного інвестування у створення сільськогосподарських кооперативів. Правові та інституційні механізми забезпечення розвитку держави та права в умовах євроінтеграиії: матеріали Міжнародної науково-практичної конферениії (20 травня 2016 р., м. Одеса), 1, 557-559.

Grigorieva, H.A. (2016). Pravovi aspekti privatnogo investuvannya u stvorennya silskogospodarskih kooperativiv. [Legal aspects of private investment in the creation of agricultural cooperatives]. Pravovi ta institucijni mekhanizmi zabezpechennya rozvitku derzhavi ta prava v umovah evrointegraciï: materiali Mizhnarodnoï naukovo-praktichnö konferencï (20 travnya 2016 r., m. Odesa). [Legal and institutional mechanisms the development of state and law in the conditions of European integration: materials of the International Scientific and Practical Conference (May 20, 2016, Odesa)], 1. 557-559. [in Ukrainian].

Давиденко, М.Л., Сірик, О.М. (2013) Сучасні проблемні питання тлумачення статті 152 Кримінального кодексу України. Правове життя сучасної України: матеріали Міжнародної наукової конференції професорсько-викладаџького та аспірантського складу (м. Одеса, 16-17 травня 2013 р.), 2, 284-285.

Davidenko, M.L., Sirik, O.M. (2013) Suchasni problemni pitannya tlumachennya statti 152 Kriminal'nogo kodeksu Ukraini. [Current issues of interpretation of Article 152 of the Criminal Code of Ukraine]. Pravove zhittya suchasnoï Ukraïni: materiali Mizhnarodnoï naukovoï konferenciï profesorsko-vikladackogo ta aspirantskogo skladu (m. Odesa, 16-17 travnya 2013 r.) [The Legal Life of Modern Ukraine: Materials of the International Scientific Conference of the Teaching and Postgraduate Students (Odessa, May 16-17, 2013)], 2, 284-285. [in Ukrainian].

\section{Odkazy na web-stránky:}

Salway, S. Contributions and challenges of cross-national comparative research in migration, ethnicity and health: insights from a preliminary study of maternal health in Germany, Canada and the UK. US National Library of Medicine National Institutes of Health. $<$ https://www.ncbi.nlm.nih.gov/pmc/articles/PMC3146864> (2017, лютий, 01).

Salway, S. Contributions and challenges of cross-national comparative research in migration, ethnicity and health: insights from a preliminary study of maternal health in Germany, Canada and the UK. US National Library of Medicine National Institutes of Health. $<$ https://www.ncbi.nlm.nih.gov/pmc/articles/PMC3146864> [in English]. (2017, February, 01). 
Hadiz, V.R., Chryssogelos A. Populism in world politics: A comparative cross-regional perspective. International Political Science Review: SAGE Journals. $<$ http://journals.sagepub.com/doi/full/10.1177/ $0192512117693908>(2017$, сентябрь, 18).

Hadiz, V.R., Chryssogelos A. Populism in world politics: A comparative cross-regional perspective. International Political Science Review: SAGE Journals. $<$ http://journals.sagepub.com/doi/full/10.1177/ $0192512117693908>$ [in English]. (2017, September, 18).

Документы, на основании которых власти РФ запрещают деятельность Меджлиса 2016. 15 минут. $<$ http://15minut.org/article/dokumenty-na-osnovanii-kotoryh-vlasti-rf-zapreshhayut-deyatelnost-medzhlisafoto-2016-02-15-19-18-31> (2017, ию).

Dokumenty, na osnovanii kotoryh vlasti RF zapreshhajut dejatel'nost' Medzhlisa 2016. [Documents on the basis of which the authorities of the Russian Federation prohibit the activities of the Mejlis]. 15 minut. [15 minutes]. <http://15minut.org/article/dokumenty-na-osnovanii-kotoryh-vlasti-rfzapreshhayut-deyatelnost-medzhlisa-foto-2016-02-15-19-18-31> [in Russian]. (2017, June, 22).

\section{Odkazy na právní předpisy a právní dokumentaci:}

Zákony a nařízení:

Закон про виконавче провадження ст. 24. 1999 (Верховна Рада України). Офіџійний вісник Украӥни, 19, 194.

Zakon pro vykonavche provadzhennya 1999 (Verkhovna Rada Ukrajiny). [Law on Enforcement 1999 (Verkhovna Rada of Ukraine)]. Oficijnyj visnik Ukrajiny [Official Bulletin of Ukraine], 19, 194. [in Ukrainian].

Цивільний кодекс, ст. 56, гл. 6. 2003 (Верховна Рада України). Офіиійний сайт Верховної Ради України. <http://zakon2.rada.gov.ua/laws/show/435-15/page5> (2013, листопад, 21).

Tsyvil'nyy kodeks 2003 (Verkhovna Rada Ukrayiny). [Civil Code 2003 (Verkhovna Rada of Ukraine)]. Ofitsiynyy sayt Verkhovnoyi Rady Ukrayiny. [The official website of the Verkhovna Rada of Ukraine]. <http://zakon2.rada.gov.ua/laws/show/435-15/page5> [in Ukrainian]. (2013, листопад, 21).

Директива о развитии двусторонних отношений Республики Беларусь с Китайской Народной Республикой 2015 (Президент Республики Беларусь). Национальный правовой Интернет-портал Республики Беларусь. <http://www.pravo.by/upload/docs/op/P01500005_1441141200.pdf> (05 мая 2017). Direktiva o razvitii dvustoronnih otnoshenij Respubliki Belarus's Kitajskoj Narodnoj Respublikoj 2015 (Prezident Respubliki Belarus'). [The Directive of the bilateral relations development of the Republic of Belarus with People's Republic of China 2015 (The President of the Republic of Belarus)]. Nacional'nyj pravovoj Internet-portal Respubliki Belarus'. [National legal Internet-portal of the Republic of Belarus]. $<$ http://www.pravo.by/upload/docs/op/P01500005_1441141200.pdf > [in Russian]. (2017, May, 05).

Проект Закону про виставкову діяльність в Украйні 2005 (Верховна Рада України). Офіційний сайт Верховної Ради України. <http://w1.c1.rada.gov.ua/pls/zweb2/webproc4_1?pf3511=25190> (01 грудня 2005).

Proekt Zakonu pro vystavkovu dijal'nist' v Ukrajini 2005 (Verkhovna Rada Ukrajiny). [The Draft Law on Exhibition Activity in Ukraine (Verkhovna Rada of Ukraine)]. Oficijnyj sajt Verkhovnoji Rady Ukrajiny [The official site of the Verkhovna Rada of Ukraine]. $<$ http://w1.c1.rada.gov.ua/pls/zweb2/ webproc4_1?pf3511=25190> [in Ukrainian]. (2005, December, 01).

Dohody, konvence, doporučení

International Covenant on Civil and Political Rights 1966 art 2. (General Assembly of the United Nations) $<$ https://treaties.un.org/doc/Publication/UNTS/Volume\%20999/volume-999-I-14668-English.pdf> (21 листопада 2016).

International Covenant on Civil and Political Rights 1966 art 2. (General Assembly of the United Nations) $<$ https://treaties.un.org/doc/Publication/UNTS/Volume\%20999/volume-999-I-14668-English.pdf> [in English]. (2016, November, 21). 
Рекомендация о развитии людских ресурсов: образование, подготовка кадров и непрерывное обучение 2004 (Международная организация труда). Офіщійний сайт Верховної Ради України. $<$ http://zakon4.rada.gov.ua/laws/show/993_532> (21 листопада 2013).

Rekomendacija o razvitii ljudskih resursov: obrazovanie, podgotovka kadrov i nepreryvnoe obuchenie 2004 (Mezhdunarodnaja organizacija truda) [Recommendation on human resources development: education, training and continuing education 2004 (International Labor Organization)]. Ofitsiynyy sayt Verkhovnoyi Rady Ukrayiny [The official website of the Verkhovna Rada of Ukraine]. <http://zakon4.rada.gov.ua/laws/ show/993_532> [in English]. (2013, November, 21)

Dvoustranné dohody

Угода про співробітництво в галузі авіаиійного пошуку і рятування 2012 (Кабінет Міністрів України та Уряд Російської Федерації) Офіиійний вісник України, 29, 130.

Ugoda pro spivrobitnytstvo v galuzi aviatsiynogo poshuku i ryatuvannya 2012 (Kabinet Ministriv Ukrayiny ta Uryad Rosiys'koyi Federatsiyi) [Agreement on cooperation in the field of aviation search and rescue 2012 (Cabinet of Ministers of Ukraine and Government of the Russian Federation)]. Oficijnyj visnik Ukrajiny [Official Bulletin of Ukraine], 29, 130. [in Ukrainian].

\section{Soudní dokumentace}

\section{Dokumentace Mezinárodního soudu}

Case concerning pulp mills on the river Uruguay. Argentina v. Uruguay [2007]. ICJ $<\mathrm{http}$ ://www.icjcij.org/files/case-related/135/15427.pdf> (12 вересня 2017)

Case concerning pulp mills on the river Uruguay. Argentina v. Uruguay [2007]. ICJ <http://www.icjcij.org/files/case-related/135/15427.pdf> [in English]. (2017, September 12)

The Vienna Convention on Consular Relations. Germany v. USA. (Request for the Indication of Provisional Measures: Order) General List No 104 [1999] ICJ 1.

The Vienna Convention on Consular Relations. Germany v. USA. (Request for the Indication of Provisional Measures: Order) General List No 104 [1999] ICJ 1. [in English].

Kauzy [soudní jednání] ECHR (do 31. ř́ína 1998)

Delta v. France (Article 50), 30 January 1990, § 38, Series A no. 191-A.

Delta v. France (Article 50), 30 January 1990, § 38, Series A no. 191-A. [in English].

Kauzy [soudní jednání] ECHR (od 1. listopadu 1998)

Campbell v. Ireland, no. 45678/98, § 24, ECHR 1999-II.

Campbell v. Ireland, no. 45678/98, § 24, ECHR 1999-II. [in English].

Soudní rozhodnutí soukromých zemí

Постановление по делу № 16-П [2013] КС РФ. <http://www.consultant.ru/document/cons_doc_

LAW_148711/> (21 июня 2016).

Postanovlenie po delu № 16-P [2013] KS RF. [Resolution in the case No. 16-P [2013] of the Constitutional Court of the Russian Federation]. <http://www.consultant.ru/document/cons_doc_LAW_148711/>

[in Russian] (2016, June 21). 


\section{Become a Contributor for the Journal}

\section{EUROPEAN POLITICAL AND LAW DISCOURSE}

The Journal is issued 6 times per year.

Articles for publication in the first (February) issue of the journal are accepted until January, 28 and will be published until February, 28.

Articles for publication in the second (April) issue of the journal are accepted until March, 28 and will be published until April, 30 .

Articles for publication in the third (June) issue of the journal are accepted until May, 28 and will be published until June, 30.

Articles for publication in the fourth (August) issue of the journal are accepted until August, 1 and will be published until August, 31 .

Articles for publication in the fifth (October) issue of the journal are accepted until September, 28 and will be published until October, 31 .

Articles for publication in the sixth (December) issue of the journal are accepted until November, 28 and will be published until December, 31.

Deadlines for acceptance of articles to the relevant journal issues are approximate. The editorial board may arbitrarily change these dates because of the large number of articles in the editorial portfolio. The dates of journal's publishing are unchangeable: the end of each pair of months.

\section{Requirements to manuscripts}

Page Limit is $10-30$ pages.

The language of articles is Czech, Ukrainian, English, Polish, French and German.

For an article in any language, the following is required in English:

an abstract (700-900 characters),

a title of the article and complete data of an author - full first and last name,

academic title, academic degree, position, and place of employment.

Footnotes are allowed, no endnotes.

Bibliography after the article is optional.

Bibliography should be arranged in accordance with the agreements of the American Psychological Association (APA).

Illustrations to articles (graphics and images) should be submitted in the TIFF or JPEG format (each image in a separate file). While preparing illustrations authors should take into account that colour printing is not available in the Journal.

The editorial board do not register and do not review for publication manuscripts that do not comply with the aforementioned requirements.

Address for service:

E-mail: admedit@eppd13.cz

eppd13@gmail.com

ediskurs@gmail.com

Web: http://eppd13.cz

Mailing Address:

BEROSTAV DRUŽSTVO, Vlastislavova 562/15, 140 00, Praha 4 - Nusle 


\section{RULES AND EXAMPLES OF REFERENCING ACCORDING TO APA-STYLE REQUIREMENTS}

\section{General rules:}

Bibliographic descriptions of sources and literature in footnotes and transliterated list of sources (references) should be arranged in accordance with the agreements of the American Psychological Association (APA). Below are examples of how to arrange the most common bibliographic sources. For more information see: http://www.apastyle.org

When arranging bibliographic descriptions of sources and literature it is necessary to consider regular and cursive (Italic) text fonts, as well as the sequence of elements in a reference.

Footnotes should be provided in the original language of a source to which you refer, that is, they are not translated or transliterated. Quotes within the article should be provided in the language of the article.

References at the end of the article should be Latinized. When making bibliographic references to Cyrillic (including Ukrainian and Russian) articles, published in journals and almanacs, we strongly recommend the following structure of references:

- Name of author/authors (transliterated);

- original title of the article transliterated by Latin symbols and its English translation in square brackets [ ];

- original title of the source transliterated by Latin symbols and its English translation in square brackets [ ];

- publisher's imprint information in English.

In References, when indicating a city of publication both in English and Cyrillic sources, the name of the city should be given in English, while the name of the publishing house should be transliterated.

For automatic transliteration of Cyrillic sources, you can use the following resources http://www.translit.ru - for sources in Russian; and http://www.slovnyk.ua/services/translit.php for sources in Ukrainian.

When arranging references on website materials, a reference should include author's name, title of the page, name of the site (typed in Italic font), site address $<\mathrm{URL}>$, marked by $<>$ symbols, and, if possible, the date when this page was last browsed (in round brackets). The month is provided in the language of the article.

For your convenience, below you can see examples of arranging bibliographic descriptions of sources and literature organized by source type; each one is given in two formats sequentially: the first one is the footnote example; the second is the example of arranging the same source in References.

\section{Monograph:}

Denning, D.E. (1998). Information Warfare and Security. Boston: Addison-Wesley Pub. Co, 99-100. Denning, D.E. (1998). Information Warfare and Security. Boston: Addison-Wesley Pub. Co. [in English]

Somit, A., Peterson, S. (2005). The Failure of Democratic Nation Building: Ideology Meets Evolution. New York: Palgrave Macmillan, 5.

Somit, A., Peterson, S. (2005). The Failure of Democratic Nation Building: Ideology Meets Evolution. New York: Palgrave Macmillan. [in English]

Тарасов, В. (1997). Советская дипломатия в период Корейской войны (1950-1953). Москва: Научная книга, 134-150.

Tarasov, V. (1997). Sovetskaya diplomatiya v period Koreyskoy voynyi (1950-1953) [Soviet diplomacy during the Korean War (1950-1953)]. Moskva: Nauchnaya kniga. [in Russian]

Калюжнова, Н.Я. Лидина, К.Л. Якобсона, А.Я. (2003). Регион на перекрестке Востока и Запада: глобализация и конкурентоспособность. Москва: ТЕИС, 14-21.

Kaljuzhnova, N.Ja., Lidina, K.L., Jakobsona, A.Ja. (2003). Region na perekrestke Vostoka i Zapada: globalizacija $i$ konkurentosposobnost [The region at the crossroads of the East and West: globalization and competitiveness]. Moscow: TEIS. [in Russian]. 


\section{Journal article:}

Bakircioglu, O. (2007). The Application of the Margin of Appreciation Doctrine in Freedom of Expression and Public Morality Cases. German Law Journal, 8, 07, 713-714.

Bakircioglu, O. (2007). The Application of the Margin of Appreciation Doctrine in Freedom of Expression and Public Morality Cases. German Law Journal, 8, 07, 713-714. [in English].

Musilová, K. (2017). Možnosti aplikace konceptu postmateriálního štěpení na substátních úrovních. Central European Political Studies Review, 19(1), 55-75. doi:http://dx.doi.org/10.5817/CEPSR.2017.1.55

Musilová, K. (2017). Mozhnosti aplikace konceptu postmaterialnigo shtepeni na substatnih urovnih. Central European Political Studies Review, 19(1), 55-75. doi:http://dx.doi.org/10.5817/CEPSR.2017.1.55 [in Czech].

Nye, J.S., Owens, W.A. (1996). America's Information Edge. Foreign Affairs, March/April, 49-67.

Nye, J.S., Owens, W.A. (1996). America's Information Edge. Foreign Affairs, March/April, 49-67. [in English].

Задорожній, О., Медведєва, М. (2006). Імплементація міжнародних стандартів захисту прав людини в сфері боротьби з інфекційними хворобами в національному праві України. Украӥнський часопис міжнародного права, 1, 64-76.

Zadorozhnii, O., Medvedieva, M. (2006). Implementatsiia mizhnarodnykh standartiv zakhystu prav liudyny $\mathrm{v}$ sferi borotby $\mathrm{z}$ infektsiinymy khvorobamy $\mathrm{v}$ natsionalnomu pravi Ukrainy [Implementation of international human rights standards to combat infection disease in domestic law Ukraine]. Ukrainskyi chasopys mizhnarodnoho prava [Ukrainian Journal of International Law], no. 1, 64-76. [in Ukrainian].

\section{Conference paper:}

Григор'єва, Х.А. (2016). Правові аспекти приватного інвестування у створення сільськогосподарських кооперативів. Правові та інституиійні механізми забезпечення розвитку держави та права в умовах євроінтеграції: матеріали Міжнародної науково-практичної конферениї (20 травня 2016 р., м. Oдеса), 1, 557-559.

Grigorieva, H.A. (2016). Pravovi aspekti privatnogo investuvannya u stvorennya silskogospodarskih kooperativiv. [Legal aspects of private investment in the creation of agricultural cooperatives]. Pravovi ta institucijni mekhanizmi zabezpechennya rozvitku derzhavi ta prava v umovah evrointegraciï: materiali Mizhnarodnoï naukovo-praktichnö̈ konferencï (20 travnya 2016 r., m. Odesa). [Legal and institutional mechanisms the development of state and law in the conditions of European integration: materials of the International Scientific and Practical Conference (May 20, 2016, Odesa)], 1. 557-559. [in Ukrainian].

Давиденко, М.Л., Сірик, О.М. (2013) Сучасні проблемні питання тлумачення статті 152 Кримінального кодексу України. Правове життя сучасної України: матеріали Міжнародної наукової конферениії професорсько-викладацького та аспірантського складу (м. Одеса, 16-17 травня 2013 р.), 2, 284-285.

Davidenko, M.L., Sirik, O.M. (2013) Suchasni problemni pitannya tlumachennya statti 152 Kriminal'nogo kodeksu Ukraini. [Current issues of interpretation of Article 152 of the Criminal Code of Ukraine]. Pravove zhittya suchasnoï Ukraïni: materiali Mizhnarodnoï naukovoï konferenciï profesorskovikladackogo ta aspirantskogo skladu (m. Odesa, 16-17 travnya $2013 \mathrm{r}$.) [The Legal Life of Modern Ukraine: Materials of the International Scientific Conference of the Teaching and Postgraduate Students (Odessa, May 16-17, 2013)], 2, 284-285. [in Ukrainian].

\section{Web-link:}

Salway, S. Contributions and challenges of cross-national comparative research in migration, ethnicity and health: insights from a preliminary study of maternal health in Germany, Canada and the UK. US National Library of Medicine National Institutes of Health. $<$ https://www.ncbi.nlm.nih.gov/pmc/articles/PMC3146864> (2017, лютий, 01).

Salway, S. Contributions and challenges of cross-national comparative research in migration, ethnicity and health: insights from a preliminary study of maternal health in Germany, Canada and the UK. US National Library of Medicine National Institutes of Health. $<$ https://www.ncbi.nlm.nih.gov/pmc/articles/PMC3146864> [in English]. (2017, February, 01). 
Hadiz, V.R., Chryssogelos A. Populism in world politics: A comparative cross-regional perspective. International Political Science Review: SAGE Journals. $<\mathrm{http}$ //journals.sagepub.com/doi/full/10.1177/ $0192512117693908>(2017$, сентябрь, 18).

Hadiz, V.R., Chryssogelos A. Populism in world politics: A comparative cross-regional perspective. International Political Science Review: SAGE Journals. $<$ http://journals.sagepub.com/doi/full/10.1177/ $0192512117693908>$ [in English]. (2017, September, 18).

Документы, на основании которых власти РФ запрещают деятельность Меджлиса 2016. 15 минут. $<$ http://15minut.org/article/dokumenty-na-osnovanii-kotoryh-vlasti-rf-zapreshhayut-deyatelnost-medzhlisafoto-2016-02-15-19-18-31> (2017, ию).

Dokumenty, na osnovanii kotoryh vlasti RF zapreshhajut dejatel'nost' Medzhlisa 2016. [Documents on the basis of which the authorities of the Russian Federation prohibit the activities of the Mejlis]. 15 minut. [15 minutes]. <http://15minut.org/article/dokumenty-na-osnovanii-kotoryh-vlasti-rfzapreshhayut-deyatelnost-medzhlisa-foto-2016-02-15-19-18-31> [in Russian]. (2017, June, 22).

\section{References to legislative acts and legal documents}

Laws and regulations

Закон про виконавче провадження ст. 24. 1999 (Верховна Рада України). Офіційний вісник Украӥни, $19,194$.

Zakon pro vykonavche provadzhennya 1999 (Verkhovna Rada Ukrajiny). [Law on Enforcement 1999 (Verkhovna Rada of Ukraine)]. Oficijnyj visnik Ukrajiny [Official Bulletin of Ukraine], 19, 194. [in Ukrainian].

Цивільний кодекс, ст. 56, гл. 6. 2003 (Верховна Рада України). Офіиійний сайт Верховної Ради України. <http://zakon2.rada.gov.ua/laws/show/435-15/page5> (2013, листопад, 21)

Tsyvil'nyy kodeks 2003 (Verkhovna Rada Ukrayiny). [Civil Code 2003 (Verkhovna Rada of Ukraine)]. Ofitsiynyy sayt Verkhovnoyi Rady Ukrayiny. [The official website of the Verkhovna Rada of Ukraine]. <http://zakon2.rada.gov.ua/laws/show/435-15/page5> [in Ukrainian]. (2013, листопад, 21).

Директива о развитии двусторонних отношений Республики Беларусь с Китайской Народной Республикой 2015 (Президент Республики Беларусь). Национальный правовой Интернет-портал Республики Беларусь. <http://www.pravo.by/upload/docs/op/P01500005_1441141200.pdf> (05 мая 2017). Direktiva o razvitii dvustoronnih otnoshenij Respubliki Belarus's Kitajskoj Narodnoj Respublikoj 2015 (Prezident Respubliki Belarus'). [The Directive of the bilateral relations development of the Republic of Belarus with People's Republic of China 2015 (The President of the Republic of Belarus)]. Nacional'nyj pravovoj Internet-portal Respubliki Belarus'. [National legal Internet-portal of the Republic of Belarus]. $<$ http://www.pravo.by/upload/docs/op/P01500005_1441141200.pdf > [in Russian]. (2017, May, 05).

Проект Закону про виставкову діяльність в Украӥні 2005 (Верховна Рада України). Офіційний сайт Верховної Ради України. <http://w1.c1.rada.gov.ua/pls/zweb2/webproc4_1?pf3511=25190> (01 грудня 2005).

Proekt Zakonu pro vystavkovu dijal'nist' v Ukrajini 2005 (Verkhovna Rada Ukrajiny). [The Draft Law on Exhibition Activity in Ukraine (Verkhovna Rada of Ukraine)]. Oficijnyj sajt Verkhovnoji Rady Ukrajiny [The official site of the Verkhovna Rada of Ukraine]. <http://w1.c1.rada.gov.ua/pls/zweb2/webproc4 1?pf3511 $=25190>$ [in Ukrainian]. (2005, December, 01).

Agreements, conventions, recommendations

International Covenant on Civil and Political Rights 1966 art 2. (General Assembly of the United Nations) $<$ https://treaties.un.org/doc/Publication/UNTS/Volume\%20999/volume-999-I-14668-English.pdf> (21 листопада 2016).

International Covenant on Civil and Political Rights 1966 art 2. (General Assembly of the United Nations) $<$ https://treaties.un.org/doc/Publication/UNTS/Volume\%20999/volume-999-I-14668-English.pdf>

[in English]. (2016, November, 21). 
Рекомендация о развитии людских ресурсов: образование, подготовка кадров и непрерывное обучение 2004 (Международная организация труда). Офіщійний сайт Верховної Ради України. $<$ http://zakon4.rada.gov.ua/laws/show/993_532> (21 листопада 2013).

Rekomendacija o razvitii ljudskih resursov: obrazovanie, podgotovka kadrov i nepreryvnoe obuchenie 2004 (Mezhdunarodnaja organizacija truda) [Recommendation on human resources development: education, training and continuing education 2004 (International Labor Organization)]. Ofitsiynyy sayt Verkhovnoyi Rady Ukrayiny [The official website of the Verkhovna Rada of Ukraine]. <http://zakon4.rada.gov.ua/laws/ show/993_532> [in English]. (2013, November, 21).

Bilateral agreements

Угода про співробітництво в галузі авіаиійного пошуку і рятування 2012 (Кабінет Міністрів України та Уряд Російської Федерації) Офіиійний вісник України, 29, 130.

Ugoda pro spivrobitnytstvo v galuzi aviatsiynogo poshuku i ryatuvannya 2012 (Kabinet Ministriv Ukrayiny ta Uryad Rosiys'koyi Federatsiyi) [Agreement on cooperation in the field of aviation search and rescue 2012 (Cabinet of Ministers of Ukraine and Government of the Russian Federation)]. Oficijnyj visnik Ukrajiny [Official Bulletin of Ukraine], 29, 130. [in Ukrainian].

\section{Judicial documents}

Documents of the International Court of Justice

Case concerning pulp mills on the river Uruguay. Argentina v. Uruguay [2007]. ICJ <http://www.icj-cij.org/ files/case-related/135/15427.pdf> (12 вересня 2017)

Case concerning pulp mills on the river Uruguay. Argentina v. Uruguay [2007]. ICJ <http://www.icj-cij.org/ files/case-related/135/15427.pdf> [in English]. (2017, September 12)

The Vienna Convention on Consular Relations. Germany v. USA. (Request for the Indication of Provisional Measures: Order) General List No 104 [1999] ICJ 1.

The Vienna Convention on Consular Relations. Germany v. USA. (Request for the Indication of Provisional Measures: Order) General List No 104 [1999] ICJ 1. [in English].

ECHR cases (until October 31, 1998)

Delta v. France (Article 50), 30 January 1990, § 38, Series A no. 191-A.

Delta v. France (Article 50), 30 January 1990, § 38, Series A no. 191-A. [in English].

ECHR cases (after November 1, 1998)

Campbell v. Ireland, no. 45678/98, § 24, ECHR 1999-II.

Campbell v. Ireland, no. 45678/98, § 24, ECHR 1999-II. [in English].

Judicial decisions of individual countries

Постановление по делу № 16-П [2013] КС РФ. <http://www.consultant.ru/document/cons_doc_LAW_ $148711 />$ (21 июня 2016).

Postanovlenie po delu № 16-P [2013] KS RF. [Resolution in the case No. 16-P [2013] of the Constitutional Court of the Russian Federation]. <http://www.consultant.ru/document/cons_doc_LAW_148711/>

[in Russian] (2016, June 21). 